\title{
Lohmannella and Simognathus (Halacaridae: Acari) from Western Australia: description of two new species and reflections on the distribution of these genera
}

\author{
Ilse Bartsch \\ Deutsches Zentrum für Marine Biodiversitätsforschung, Forschungsinstitut Senckenberg, \\ Notkestr. 85, 22607 Hamburg, Germany, e-mail: bartsch@meeresforschung.de
}

\begin{abstract}
Two new littoral species, Lohmannella septemsetosa sp. nov. and Simognathus cruciferus sp. nov. are described and the description of L. pinggi Otto, 1994 is supplemented. The genera Lohmannella and Simognathus are distributed world-wide. More species are recorded from the southern than northern hemisphere. Lohmannella is abundant in warm-temperate to polar regions but rare in the tropics. In contrast, most records of Simognathus are from tropical and warm-temperate areas. According to external morphological characters and distribution, different lineages of Lohmannella species developed in the north and south. Simognathus demonstrates no such northsouth discrimination.
\end{abstract}

\section{INTRODUCTION}

The two genera Lohmannella and Simognathus include 35 and 43 species and subspecies, respectively (to the end of 2004). Representatives of both are distributed world-wide, but there is a distinct difference between the faunas of the northern and southern hemisphere. Simognathus is more diverse in the south than in the north (Bartsch 1994, 2004). More marine Lohmannella species are recorded from the southern than northern hemisphere, though locally species diversity is high in the north, too. Both genera are present in Western Australia. One Lohmannella species has been described from Rottnest Island, off Perth (Bartsch 1993b). A record of another species and the description of a new species, from Esperance, will be presented in this paper. Ten Simognathus species are already known to belong to the Western Australian fauna (Bartsch 1993b, 1994, 2003b), and a new species from Esperance is described below.

\section{MATERIAL AND METHODS}

The material studied was collected during Marine Biological Workshops held in Western Australia, on Rottnest Island and in Esperance. The fauna and flora around Rottnest Island is dominated by warmtemperate species, although strongly influenced by tropical elements (Wells and Walker 1993). Esperance lies within the warm-temperate zone (Knox 1963; Wilson and Allen 1987; Ponder and Wells 1998; O'Hara and Poore 2000).

The material was collected by the author. The mites were cleared in lactic acid and mounted in glycerine jelly. Slides with holotypes and voucher specimens are deposited in the Western Australian Museum, Perth (WAM), apart from one Lohmannella specimen in the Zoological Institute and Museum in Hamburg (ZMH).

Abbreviations used in the descriptions are as follows: $\mathrm{AD}$, anterior dorsal plate; $\mathrm{AE}$, anterior epimeral plate; ds- 1 to ds-5, first to fifth pair of dorsal setae numbered from anterior backward; GA, genitoanal plate; glp-1 to glp-5, pair of gland pores numbered 1 to 5 from anterior backward;GO, genital opening; GP, genital plate; OC, ocular plate(s); P-2 to P-4, second to fourth palpal segment; pas, parambulacral seta(e); $P D$, posterior dorsal plate; PE, posterior epimeral plate(s); pgs, perigenital setae; sgs, subgenital setae. The legs, their segments and claws are numbered I to IV. The leg segments 1 to 6 are trochanter, basifemur, telofemur, genu, tibia, and tarsus. The setation formula of the legs is presenting the number of setae from trochanter to tarsus.

The position of a seta is given in a decimal system, with reference to the length from anterior to posterior or basal to distal.

\section{SYSTEMATICS}

Family Halacaridae Murray, 1877

Subfamily Lohmannellinae Viets, 1927

Genus Lohmannella Trouessart, 1901

Lohmannella septemsetosa sp. nov. Figures $1 \mathrm{~A}-\mathrm{K}, 2 \mathrm{~A}-\mathrm{F}$ 

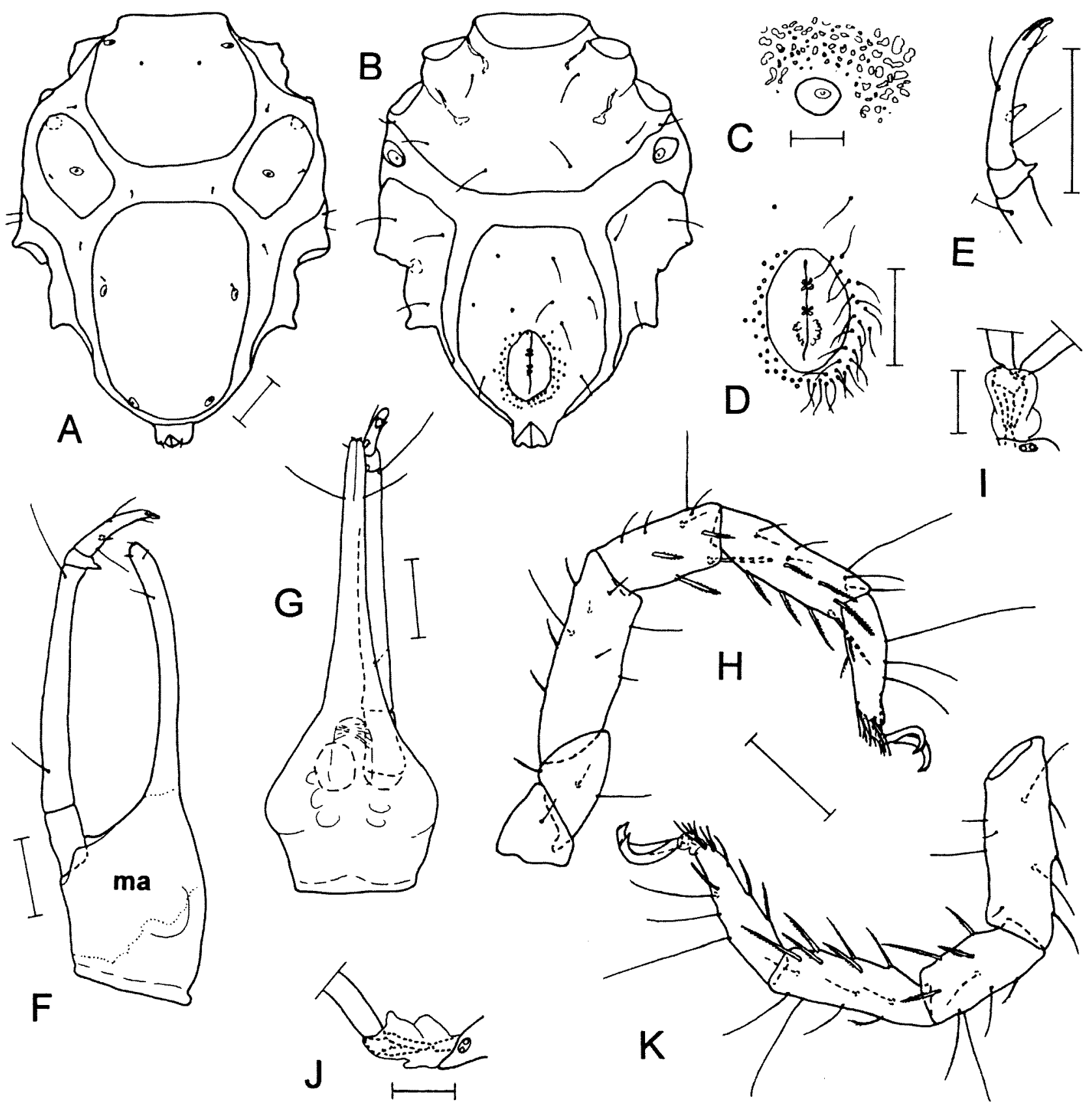

Figure 1 A-K. Lohmannella septemsetosa sp. nov., holotype male. A, Idiosoma, dorsal; B, idiosoma, ventral; C, part of OC with gland pore; D, genital opening; E, P-3 and P-4, lateral; F, gnathosoma, lateral (stippled area enclosing maze-like structured integument); $\mathrm{G}$, gnathosoma, ventral; $\mathrm{H}$, leg I, medial; I, ambulacrum of tarsus I, ventral; J, ambulacrum of tarsus II, medial; $\mathrm{K}$, telofemur to tarsus II, medial. (ma, area with mazelike epicuticula). A, B, D-H, K: scale $=50 \mu \mathrm{m} ; \mathrm{C}, \mathrm{I}$, J: scale $=10 \mu \mathrm{m}$.

\section{Material Examined}

\section{Holotype}

Male, Lucky Bay, Cape le Grand, 33⒌'S, $122^{\circ} 13^{\prime} \mathrm{E}$, near Esperance, Western Australia, Australia; algal tufts with sediment, $30 \mathrm{~cm}$ below water edge, 15 February 2003 (WAM T62841).

\section{Paratype}

One deutonymph, same data as for holotype (WAM T62842).

\section{Diagnosis}

Idiosomal length $410 \mu \mathrm{m}$, gnathosomal length 284 $\mu \mathrm{m}$, ratio idiosoma:gnathosoma 0.69 . Surface of plates with reticulate and maze-like ornamented epicuticula. Gland pores large. Pair of ds-1 posterior to level of gland pores. OC with gland pore in middle of plate. P-2 without spiniform ventral process. Genu and tibia I with four and seven bipectinate ventral setae. Tarsi I to IV with 2, 2, 3, 2 bipectinate ventral setae. Claws with accessory process. 


\section{Description}

Male

Idiosoma. Length $410 \mu \mathrm{m}$, width $302 \mu \mathrm{m}$. Dorsal plates covered by delicately reticulate or maze-like epicuticula. Length of $\mathrm{AD} 142 \mu \mathrm{m}$, width $159 \mu \mathrm{m}$; pair of gland pores with wide, oblong alveolus, almost $10 \mu \mathrm{m}$ in width (Figure 1C). Length of OC $102 \mu \mathrm{m}$, width $57 \mu \mathrm{m}$. Gland pore in middle of plate, pore canaliculus at the same level but in lateral margin (Figure 1A). A very faint, comea-like structure near anterior margin. Length of PD 202 $\mu \mathrm{m}$, width $150 \mu \mathrm{m}$, anterior margin truncate, with broadly rounded corners. With two pairs of large gland pores as illustrated. Pair of ds-1 (setae broken) posterior to the level of pair of gland pores. Following pairs of setae small; ds $-2, \mathrm{ds}-3$ and $\mathrm{ds}-4$ within striated integument, ds-5 immediately anterior to glp-4. Adanal setae on anal cone.

Ventral plates with maze-like or irregularly reticulate or foveate epicuticula. Length of AE 137 $\mu \mathrm{m}$, width $269 \mu \mathrm{m}$. Pair of platelets between AE and PE, each platelet with large gland pore (Figure 1B). Length of PE $179 \mu \mathrm{m}$; each plate with two dorsal and three ventral setae. Length of GA 207 $\mu \mathrm{m}$, width $144 \mu \mathrm{m}$; anterior margin truncate. Plate with about nine outlying setae and 52 setae close around GO (Figure 1D). Length of GO $63 \mu \mathrm{m}$, width $43 \mu \mathrm{m}$; distance between anterior margin of $\mathrm{GO}$ and that of GA equalling 1.5 times length of GO. Genital sclerites with four pairs of spurlike sgs. Three pairs of internal genital acetabula shining through genital sclerites.

Gnathosoma. Slender, length $284 \mu \mathrm{m}$, or 0.69 times of idiosomal length. Width of gnathosoma $107 \mu \mathrm{m}$, length:width ratio 1:0.27. Lateral flank of gnathosomal base with an area with maze-like ornamented epicuticula (Figure 1F). Pharyngeal plate far from reaching posterior margin of gnathosoma (Figure 1G). Rostrum slender, much
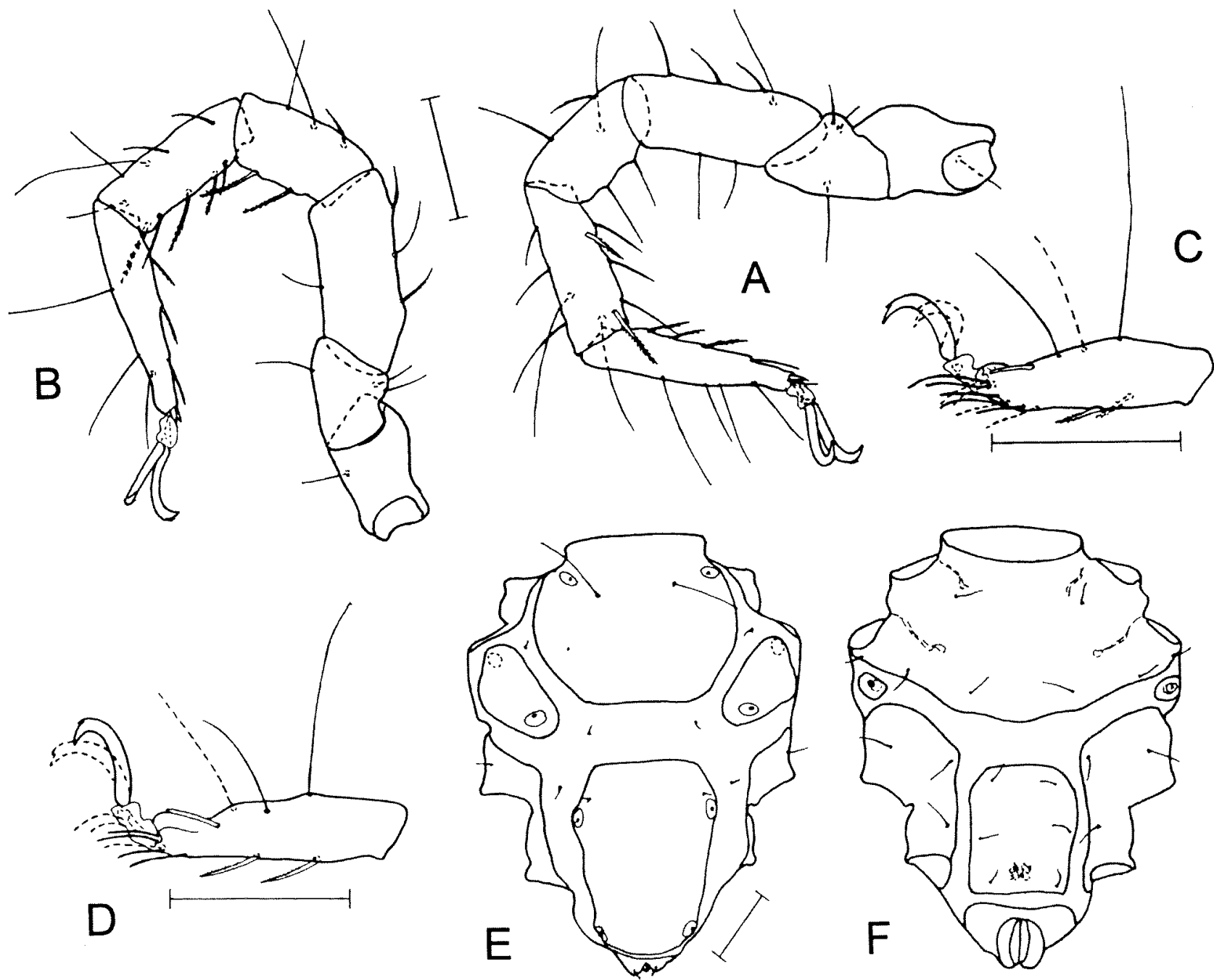

Figure 2 A-F. Lolmannella septemsetosa sp. nov. A, Leg III, medial, male; B, leg IV, medial, male; C, tarsus I, lateral, male (medial setae and claw in broken line); D, tarsus II, medial, male (lateral setae and claw in broken line); E, idiosoma, dorsal, deutonymph; $F$, idiosoma, ventral, deutonymph. Scale $=50 \mu \mathrm{m}$. 
longer than gnathosomal base. Both pairs of maxillary setae short and situated in posterior quarter of rostrum. Palps slender. P-2 with two setae, basal setae near segment's base, at 0.2. P-3 with spur-like process (no spine). Basal portion of P-4 with two slender setae and one spur, apical portion with solenidion, small seta and spur-like tip (Figure 1E).

Legs. Slender, integument with maze-like sculpturing. Leg I slighly longer, leg IV shorter than idiosoma. Telofemur I about 3.4 times longer than high (Figure $1 \mathrm{H}$ ). Leg chaetotaxy (pas excluded, solenidia included): leg I, 1, 3, 9, 9, 14, 11 (Figure 1H); leg II, 1, 3, 9, 9, 13, 9 (Figure 1K); leg III, 1, 3, 6, 5, 10, 8 (Figure 2A); leg IV, 1, 3, 4, 5, 10, 6 (Figure 2B). Several of short dorsal setae delicately serrate. Genua I to IV with 4, 4, 2, 2 ventral setae; setae of genua I, II and IV bipectinate. Tibiae I to IV with 7 , $6,5,5$ ventral setae; $7,4,2,3$ of these setae bipectinate. Tarsi I to IV with $4,4,4,3$ dorsal setae, solenidia included. Solenidion of tarsus I $11 \mu \mathrm{m}$ in length and in dorsolateral position (Figure 2C); on tarsus II solenidion $14 \mu \mathrm{m}$ in length and in dorsal position (Figure 2D). Tarsi I to IV with 2, 2, 3, 2 bipectinate ventral setae and 5, 3,1,1 slender setae. Tarsus I with pair of doubled pas; tarsus II with medial pas doubled, lateral pas single; tarsus III with spiniform lateral pas and a seti- plus a spiniform medial pas; pair of pas of tarsus IV spiniform.

Claws with accessory process. Central sclerite small, without claw-like process. All tarsi with carpite between end of tarsi and claws (Figure 1I and J). Carpite divaricate, $9 \mu \mathrm{m}$ in length.

\section{Deutonymph}

Idiosomal length $290 \mu \mathrm{m}$. Shape of AD similar to that of male. OC shorter; pair of gland pores close to posterior corner of plate (Figure 2E). PD shorter and more narrow than that plate of male. AE with four pairs of setae (Figure 2F); PE with one dorsal and three ventral setae. GP and anal plate separated. GP with three pairs of pgs and two pairs of minute, seta-like sgs. Length of gnathosoma 116 $\mu \mathrm{m}$, i.e. 0.80 of idiosomal length. Leg chaetotaxy: leg I, 1, 3, 5-6, 5-6, 10, 9; leg II, 1, 3, 5-6, 6, 9, 7; leg III, 1, 3, 4, 4, 7, 6; leg IV, 1, 1, 2, 3, 6, 4, 4. Genu I with pair of bipectinate setae. On genu II ventromedial seta bipectinate, ventrolateral seta slender and very faintly pectinated. Ventral seta of genu III slender, that seta of genu IV bipectinate. Tibia I with two ventromedial and three ventrolateral setae, these five setae bipectinate. Tibia II with two pairs of bipectinate setae. Tibia III with one large bipectinate and one short, slightly pectinate seta, and tibia IV with two to three strong, bipectinate setae. Tarsi I-IV with 2, 2, 2, 1 bipectinate ventral setae and $3,1,0,0$ eupathid ventral setae.

\section{Etymology}

The specific name is derived from septem (Latin), seven, and setosus (Latin), with setae, as tibia I of this species bears seven ventral setae.

\section{Remarks}

The most conspicuous characters of Lohmannella septemsetosa are the gland pores with large alveoli and the seven bipectinate ventral setae on tibia I. A similar combination of characters is present in $L$. dictyota Bartsch, 1992, L. gaussi Lohmann, 1907, L. kerguelensis Lohmann, 1907, and L. pinggi Otto, 1994. Records of $L$. dictyota are from the southwestern Pacific, from the Society Islands, the Coral Sea and Great Barrier Reef (Bartsch 1992; Otto 2000). L. pinggi is known from Victoria and New South Wales, Australia (Otto 1994), L. gaussi from Antarctica and sub-Antarctica, from off Wilhelm II Land, the islands Crozet, Marion and South Sandwich (Lohmann 1907; Bartsch 1979a, 1993a; Newell 1984), and L. kerguelensis from the Kerguelen Islands and Palmer Archipelago (Lohmann 1907; Bartsch 1993a). Lohmannella dictyota has an unusual elongate PD with a prominent ornamentation, the ds -3 are situated on the $P D$, the pair of gland pores 2 are in the medial corners of the $O C$, and the P-2 has a spiniform ventral process. Lohmannella gaussi is, compared with congeners, large-sized, its legs and gnathosoma are long and slender; the glp-2 are near the lateral margin of the $O C$, and the PD bears a V-shaped porose area, characters not present in $L$. septemsetosa. In contrast to L. septemsetosa the OC of $L$. kerguelensis has a cornea and the ds- 3 are in the anterior rounded margin of PD. Lohmannella pinggi has much shorter legs than $L$. septemsetosa, elongate $O C$ and the ds- 1 are situated distinctly anterior to the level of gland pore 1 .

\section{Lohmannella pinggi Otto, 1994 Figure $3 \mathrm{~A}-\mathrm{G}$}

Lohmannella pinggi Otto, 1994: 32-35, figures 1-8.

\section{Material Examined}

One female, Rottnest Island, Cape Vlamingh, ca $32^{\circ} 02^{\prime} \mathrm{S}, 115^{\circ} 27^{\prime} \mathrm{E}$, Western Australia, Australia; from corallines on rocky platform, 10 January 1991 (WAM T62843). One female, Rottnest Island, Cape Vlamingh; from corallines on rocky platform, 9 January 1991 (WAM T62844). One female (damaged), Rottnest Island, Cape Vlamingh, Western Australia, Australia; from corallines on rocky platform, 9 January 1991 (ZMH).

\section{Diagnosis}

Idiosomal length 279-303 $\mu \mathrm{m}$, gnathosomal length 192-197 $\mu \mathrm{m}$. Dorsal plates delicately reticulated. OC oblong, its length more than twice the width. With five pairs of large gland pores; glp- 

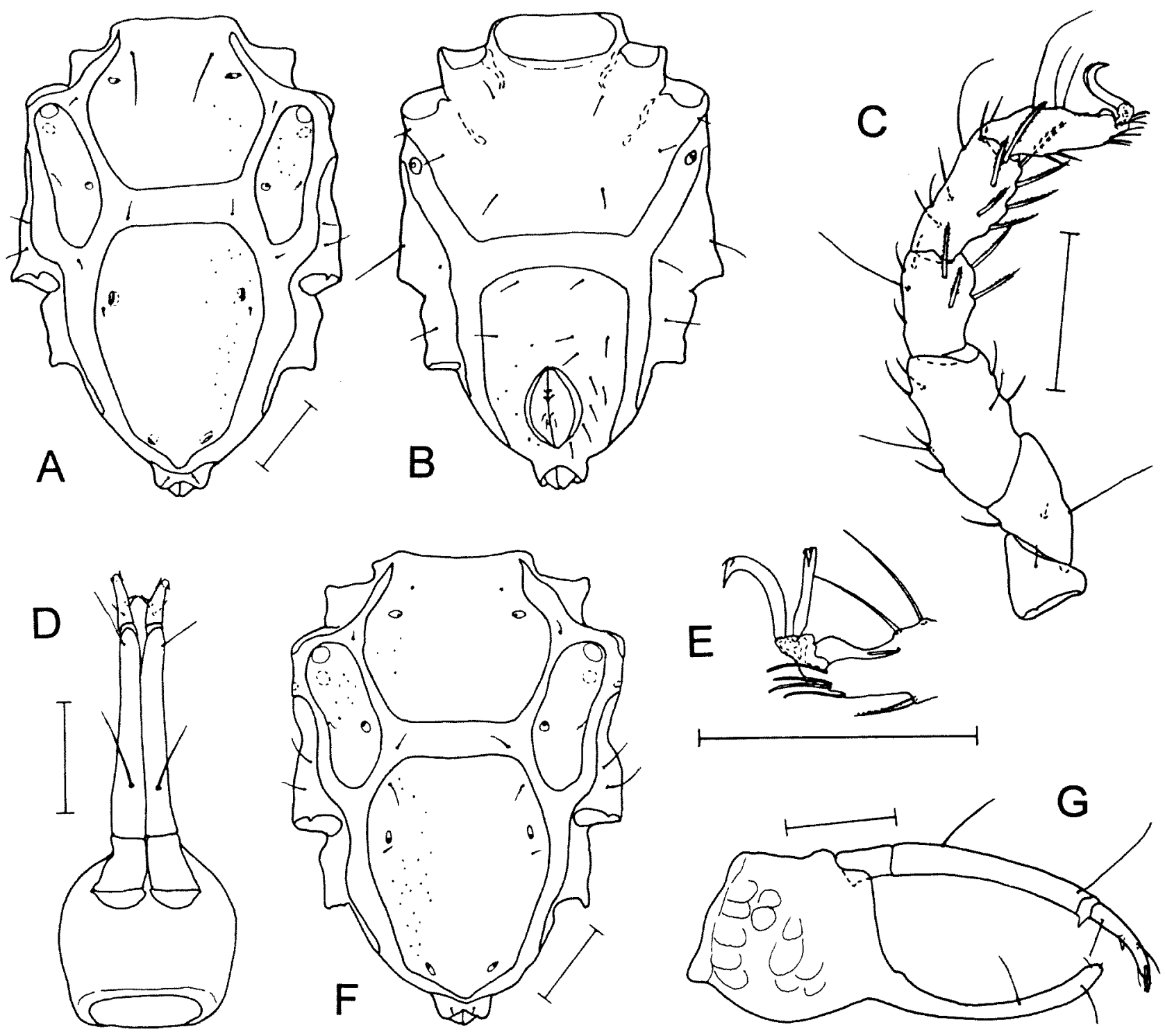

Figure 3 A-G. Lohmannella pinggi Otto, 1984, female. A, Idiosoma, dorsal; B, idiosoma, ventral; C, leg I, medial; D, gnathosoma, dorsal; E, tip of tarsus II, medial; F, idiosoma, dorsal, G, gnathosoma, lateral. Scale $=50 \mu \mathrm{m}$.

3 near medial margin of OC. Pair of ds-1 anterior to level of gland pores. Female GA with nine pairs of pgs. Gnathosoma 2.4 times longer than wide, length ratio idiosoma to gnathosoma 1:0.65. No ventral spiniform process on P-2. Basal seta of P-2 strong, situated in basal half. Genu I with two pairs of bipectinate setae; tibia I with seven such setae. Tarsi I to IV with 2, 2, 4, 2 bipectinate ventral setae. Accessory process of claws with minute tines.

\section{Supplementary Description}

Idiosomal length 279 and $303 \mu \mathrm{m}$, gnathosomal length 192 and $197 \mu \mathrm{m}$. Dorsal plates delicately reticulated and with scattered deep canaliculi (Figure $3 \mathrm{~A}$ ). OC oblong, length more than twice its width; anterior cornea distinct, posterior one faint. Gland pores distinct, their alveoli $7 \mu \mathrm{m}$ in width; glp-2 in ventral position, glp-3 on $O C$ near its medial margin, at about 0.57. Pair of ds-1 anterior to the level of gland pores. Two females (WAM T62843 and ZMH) with ds-2, ds-3 and ds-4 within striated integument (Figure 3A); ds-5 adjacent to glp-4. One female (WAM T62844) with pair of ds-4 situated on PD (Figure 3F). PE long, extending anteriad beyond middle of OC. Female with 18 pgs. Interval between anterior margin of GA and GO equalling 1.1 times the length of the latter. Gnathosomal length 192 and $197 \mu \mathrm{m}$, i.e., $0.65-0.69$ of idiosomal length. P-2 without ventral process (Figure $3 G$ ); its basal seta situated at 0.22 (Figure 3D). Legs short. Genua and tibiae with articular membranes; tarsi with small fossa membranes. Length:height ratio of telofemora I and II 2.0, that of telofemora III and IV 1.6. Leg chaetotaxy (solenidia included, pas excluded): leg I, 1, 3, 8, 8, 13, 10; leg II, 1, 3, 8, 8, 12, 9; leg III, 1, 3, 
6, 4-5, 9, 8; leg IV, 1, 3, 4, 4, 8, 5-6. Number of bipectinate ventral setae of genua I to IV: $4,2,0,1$; of tibia I to IV: $7,3,1,4$ (one of the latter slender); of tarsi I to IV: 2, 2, 4, 2. Tarsus I with four dorsal setae (solenidion included), two bipectinate ventral setae, two pairs of ventral eupathia and a pair of pas (Figure 3E); lateral pas doubled. Tarsus II with four dorsal setae, three ventral eupathidia and pair of pas; lateral pas doubled. Tarsus III with four dorsal setae and pair of pas, lateral pas setiform, medial pas including both a seti- and spiniform seta. Tarsus IV with three dorsal setae, none or one smooth ventral seta and pair of spiniform pas. Accessory process of claws with two tines (Figure 3E).

\section{Remarks}

Three females were taken amongst shallow water corallines, of which two agree almost perfectly with the description of L. pinggi by Otto (1994). Differences are: the somewhat smaller size (303 $\mu \mathrm{m}$ vs $378-437 \mu \mathrm{m}$ ), shape of ds-1 (long and slender vs spiniform), number of corneae (two vs one), presence of the ds-5 (vs absence), number of setae on $\mathrm{AE}$ (four vs three pairs) and number of dorsal setae of the legs. The five last mentioned differences are thought to be due to either a range of great variability in the type series or inadequate description; the difference in size may partly be due to the mounting.

One of the present females has the ds-4 inserted on the PD instead, as usual, within the striated integument posterior to the OC. Apart from this character, that female agrees with the other specimens. In most of the Lohmannella species the ds-2, ds-3 and ds-4 are situated on tiny sclerites within the striated integument; intraspecific variations, if present at all, are expected to be within a very limited range. The ds-2 in general are between the $A D$ and $O C$, in some few species the ds-2 are in or on the lateral margin of the $A D$. The ds-3 are anterior to the $\mathrm{PD}$, in ten species the setae are in the margin or on the PD; the ds- 4 are inserted immediately posterior to the OC; one exception is $L$. multispina Newell, 1984 where the setae are found in the corner of the $\mathrm{OC}$, other exceptions are the freshwater species, i.e., L. andrei (Angelier, 1951), $L$. heptapegoni Petrova, 1966, L. curvimandibulata (Petrova, 1969), L. cvetkovi (Petrova, 1965), and L. stammeri Viets, 1939. In these species both the ds-4 and ds- 5 are inserted on the PD. These five species live in nearshore and continental waters in countries around the Mediterranean (Bartsch 1996; Pesic 2004).

\section{Subfamily Simognathinae Viets, 1927}

\section{Genus Simognathus Trouessart, 1889}

Simognathus cruciferus sp. nov. Figure $4 \mathrm{~A}-\mathrm{L}$

Material Examined

Holotype

Female, Duke of Orleans Bay, ca $33^{\circ} 55^{\prime} \mathrm{S}$, $122^{\circ} 35^{\prime} \mathrm{E}$, near Esperance, Western Australia, Australia; demosponge overgrown with green algae and corallines, just below water line, 17 February 2003 (WAM T62845).

\section{Diagnosis}

Idiosomal length $375 \mu \mathrm{m}$. Dorsal plates colourless, almost uniformly foveate and with numerous delicate canaliculi. $\mathrm{AD}$ and $\mathrm{OC}$ with cornea-like structures. OC almost triangular. Pair of ds-4 on PD. Adanal setae in ventral position. AE with marginal areolae with foveae and canaliculi, integument in a cross-shaped median area almost smooth. GA with such smooth integument in a T-shaped area. Anterior margin of female GA arched. P-2 with ventral protuberance and bristle. Tibia I with wide but short, bluntly ending spine.

\section{Description}

\section{Female}

Idiosoma. Length $375 \mu \mathrm{m}$, width $200 \mu \mathrm{m}$. Dorsal plates almost uniformly foveate (Figure $4 \mathrm{~A}$ ), each fovea surrounded by delicate canaliculi. All plates colourless. Length of AD $157 \mu \mathrm{m}$, width $97 \mu \mathrm{m}$; its posterior margin truncate. First pair of gland pores small, slightly posterior to the level of insertion of leg I. An ovate smooth area near anterior margin. Length of OC $40 \mu \mathrm{m}$, width $24 \mu \mathrm{m}$, with ovate cornea. Length of PD $165 \mu \mathrm{m}$, width $95 \mu \mathrm{m}, 1.7$ times longer than wide. Dorsal setae small. Pair of ds- 1 on AD close to pair of gland pores. Pair of ds-2 within striated integument immediately anterior to OC. Pair of ds-3 in distolateral corners of AD; ds-4 and ds-5 on PD; adanal setae on anal cone, in ventral position.

AE marginally foveate but smooth immediately posterior to insertion of legs $I$ and $I I$ and in a ventral cross-shaped area (Figure 4B). Foveae surrounded by delicate canaliculi. Two pairs of internal scars (muscle attachment) in middle of cruciform area. Length of AE $142 \mu \mathrm{m}$, width 199 $\mu \mathrm{m}$; epimeral processes I large, slightly raised, epimeral vesicles large, with three pairs of ventral setae, posteriormost pair only slightly posterior to second pair of setae. Length of PE $177 \mu \mathrm{m}$. Length of GA $155 \mu \mathrm{m}$, width $108 \mu \mathrm{m}$, integument in a Tshaped area almost smooth, remainder foveate. Length of GO $43 \mu \mathrm{m}$, width $25 \mu \mathrm{m}$; distance between anterior margin of GO and that of GA 1.7 times length of GO. With four pairs of pgs on either side of GO. 


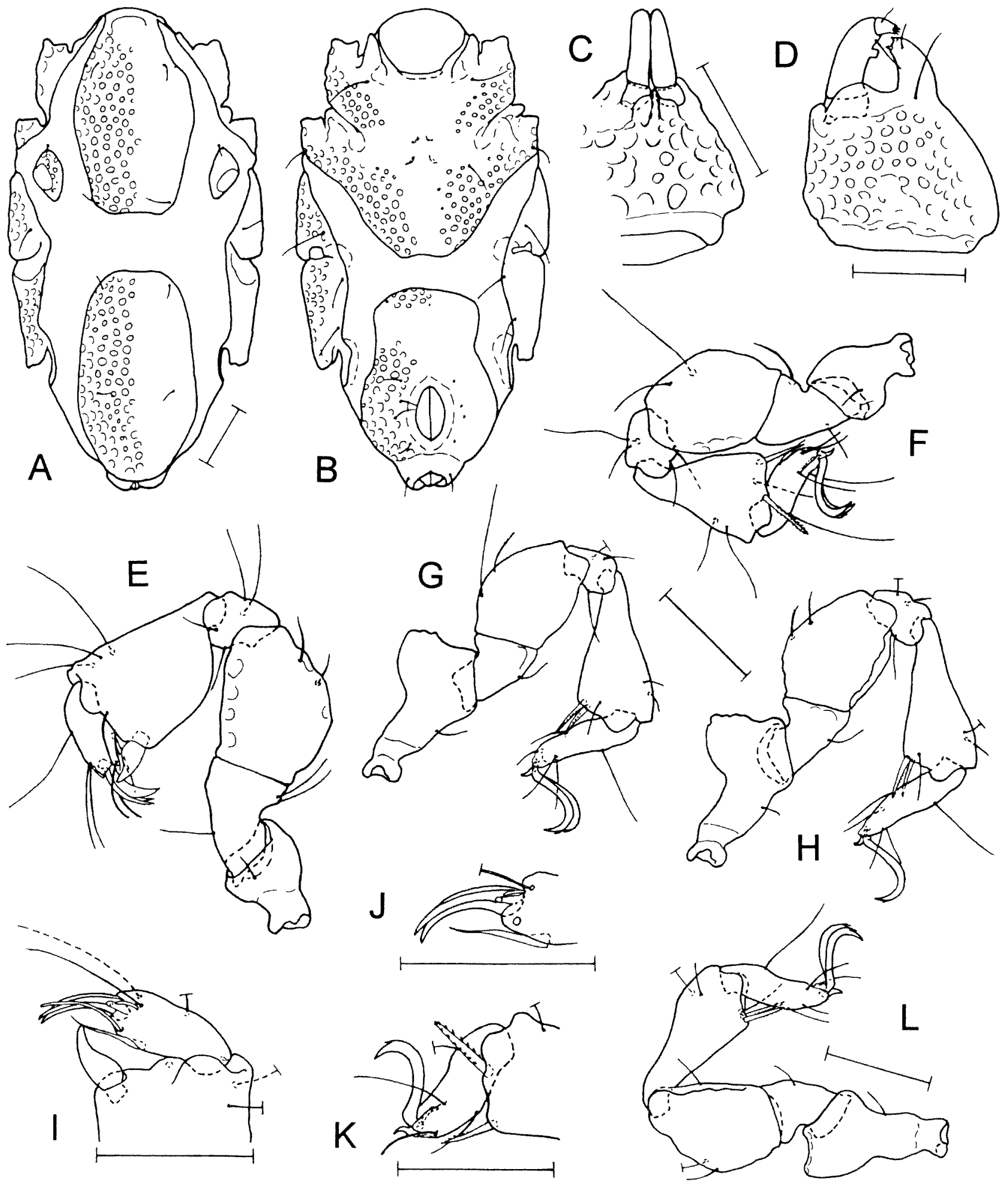

Figure 4 A-L. Simognathus cruciferus sp. nov., holotype female. A, Idiosoma, dorsal; B, idiosoma, ventral; C, gnathosoma, dorsal; D, gnathosoma, lateral; E, leg I, medial; F, leg II, medial; G, leg III, lateral; H, leg IV, lateral; I, tarsus and tibia I, lateral (medial parambulacral seta and claw omitted, other medial setae in broken line); I, tip of tarsus I, lateral (parambulacral seta, medial claw and fossary seta omitted), $K$, tarsus and tibia II, medial (lateral setae omitted); L, leg IV, medial. Scale $=50 \mu \mathrm{m}$.

Gnathosoma. Length $97 \mu \mathrm{m}$, width $85 \mu \mathrm{m}$. Integument of gnathosomal base foveate. Rostrum short. Basal pair of maxillary setae near base of rostrum, apical pair of setae shorter, in posterior third of rostrum (Figure 4D). Tip of rostrum with two pairs of rostral setae. Palps three-segmented; inserted adjacent. In dorsal aspect tectum with median keel, else scale-like and partly obscuring palpal base (Figure 4C). P-2 with ventral protuberance and one bristle-like seta (Figure 4D). 
Third segment short, with one basal seta and three short, stout apical setae.

Legs. Integument almost smooth. Length:height ratio of telofemora 1.4. Tibiae club-shaped, length:height ratio of tibiae I and II 1.5, that of tibiae III and IV 2.2 (Figure 4E-H). Tibiae longer than telofemora. Leg chaetotaxy (solenidia excluded, pas included): leg I, 1, 2-3, 2, 4, 5, 6; leg II, 1, 2, 2, 4, 5, 6; legs III and IV, 1, 1, 2, 3, 5, 5. Spine of tibia I wide but short, ending bluntly (Figure 4I). Tibia II with two stout, roughly bipectinate setae (Figure 4K); tibiae III and IV each with pair of bipectinate setae. Tarsus I with tapering ventral seta and pair of pas singlets, three dorsal setae, a short dorsolateral solenidion adjacent to digitiform famulus (Figure 4J). Tarsus II with slender ventral seta, pair of pas singlets, three dorsal setae and a solenidion, $6 \mu \mathrm{m}$ long, adjacent to short medial fossa membrane (Figure $4 \mathrm{~K})$. Tarsi III and IV each with three dorsal setae, single ventral seta, one medial pas, but no lateral pas.

Paired claws of tarsus I rather slender, scytheshaped, smooth, median claw stout. Paired claws of tarsi II to IV similar in width, claw-shaped with accessory process. Median claw minute.

\section{Abnormality}

One of the fourth legs is five-segmented (Figure $4 \mathrm{~L}$ ), its genu is absent, the telofemur bears a ventral seta (which is absent in 'normal' legs), the tibia is somewhat longer than its counterpart.

\section{Etymology}

The specific name is derived from crux (Latin), a cross, and ferre (Latin), to bear, as on the $\mathrm{AE}$ the shape of the area with smooth integument resembles a cross.

\section{Remarks}

The species belonging to Simognathus can roughly be divided into those with distinct, more or less triangular $O C$ and those with the $O C$ reduced to narrow sclerites, Simognathus cruciferus is a species with distinct $\mathrm{OC}$. Other easily recognized characters are (1) the ornamentation of the dorsal plates, (2) the ornamentation of the ventral plates, and (3) the absence or presence of a ventral protuberance on $\mathrm{P}$ 2 and the insertion of the seta relative to the protuberance. In S. cruciferus the dorsal plates are uniformly foveate; a rather narrow cruciform central area of the $\mathrm{AE}$ is smooth, its large marginal areas are foveate; $\mathrm{P}-2$ bears a distinct protuberance separated from the seta. With recently described species included (Chatterjee and Chang 2004; Pepato and Tiago 2004; Bartsch 2004, present paper), 44 species are known, 18 of them having the OC reduced to sclerites. In the remaining 26 species, with rather large $O C$, the $A E$ is either foveate in the margins as well as in the median, or the foveate ornamentation is present only marginally and the integument in a large median area is delicately porose or almost smooth. Simognathus cruciferus is at present the only species with smooth integument in a narrow cruciform area.

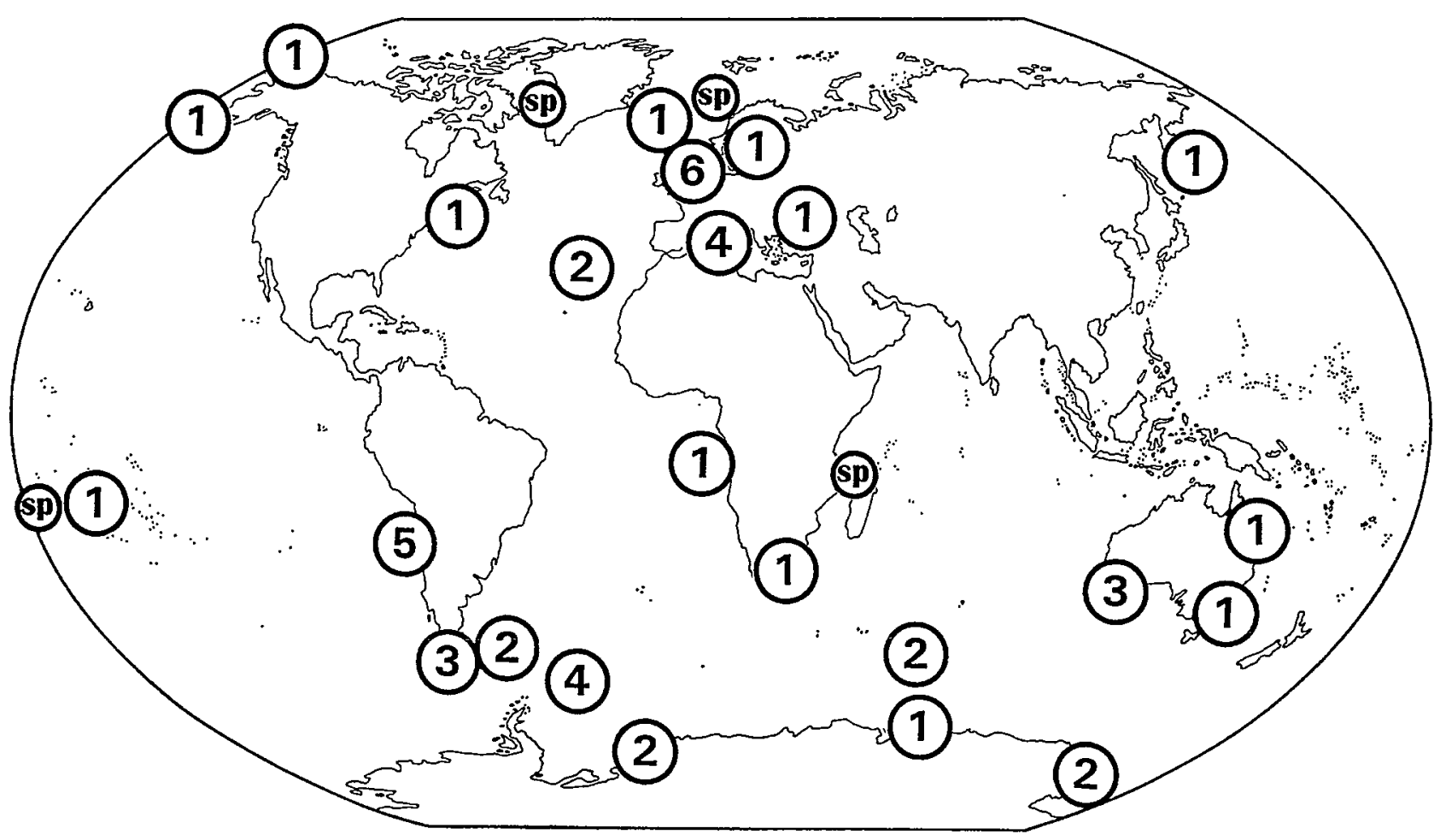

Figure 5 Distribution of the genus Lohmannella and number of species in relevant areas. 


\section{GEOGRAPHICAL DISTRIBUTION OF THE GENERA LOHMANNELLA AND SIMOGNATHUS}

With the inclusion of the above described species, 36 Lohmannella subspecies/species are known (Tables 1 and 2). The genus is spread all over the globe. Apart from marine representatives (Table 1) there are also five freshwater species (Table 2). Lohmannella inhabits cavernicolous or mesopsammal habitats, and is present amongst tufts of epiphytic and epilithic algae, corallines or colonies of bryozoans and hydrozoans, coarse sand and rubble. The genus inhabits a depth range from the lower tidal zone to the abyss. The genus seems to be diverse in Antarctic, sub-Antarctic and coldtemperate South American waters and in the Mediterranean and English Channel area (Figure 5). In contrast, a single species is recorded from the north-western Atlantic (Newell 1947; Bartsch 1979b) and one (?) species from the Northern Pacific Ocean, from Alaska, Kamchatka and the Kuril Islands (Newell 1951; Makarova 1977, 1978). The genus seems to be rare in the tropics. One record is from shallow water, viz. $L$. dictyota from the Society Islands and tropical Queensland (Bartsch 1992; Otto 2000). Other species from low latitudes, L. cygna Bartsch, 1988 , from ca $9^{\circ} \mathrm{S}, 12^{\circ} \mathrm{E}$, and Lohmannella sp. from $11^{\circ} \mathrm{S}, 47^{\circ} \mathrm{E}$, are from depths greater than $400 \mathrm{~m}$ (Bartsch 1982, 1988a). There is a predominance of species in the south, with 21 vs 10 marine subspecies/species in the north (Table 1).
To the latter figure three more species might be added: the specimens from the depth in the Norwegian Basin, from $64-69^{\circ} \mathrm{N}, 0-10^{\circ} \mathrm{E}$ (Bartsch 1978), from the Sula coral reef off Norway, $64^{\circ} \mathrm{N}$, $8^{\circ} \mathrm{E}$ (Bartsch 2003a), and an undescribed species from eastern Greenland. The freshwater species are not included.

One very obvious character of Lohmannella species is the presence and size of the gland pores. All five pairs may be distinct, often within large alveoli (as described above), or one or more pairs of gland pores are minute, hardly recognizable and hence often not mentioned in species descriptions. All northern Atlantic species have minute or inconspicuous gland pores, whereas many southern shallow water species have pores within large alveoli. In the deep-water species all five pairs of pores are present (although they may be replaced by setulae) but the pores are small. Spiniform processes on the second palpal segment are present in about one-third of southern hemisphere species, in species living in tidal and shallow subtidal coarse sand and rubble. Northern species have four to six bipectinate ventral setae on tibia I, southern species five to eight such setae.

The genus Simognathus is distributed in all oceans, in tropical, warm- and cold-temperate and sub-Antarctic biogeographical provinces. Its absence from the Arctic and Antarctic regions may be due to restricted sampling. Records of Simognathus are from the low water edge to

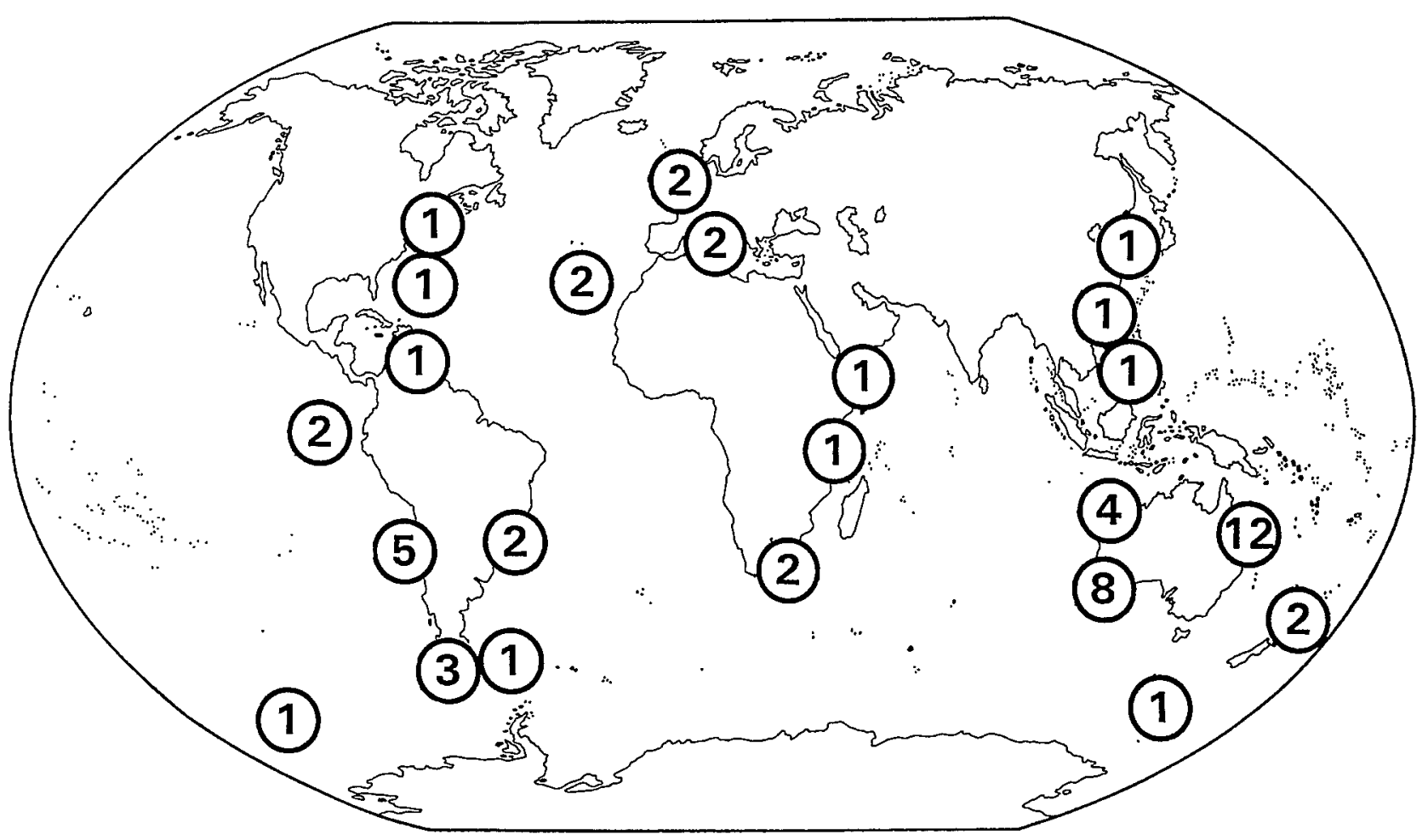

Figure 6 Distribution of the genus Simognathus and number of species in relevant areas. 
Table 1 The genus Lohmannella. List of marine species, morphological characters and collecting data.

\begin{tabular}{|c|c|c|c|c|c|c|c|c|c|}
\hline species & I & II & III & IV & $\mathrm{V}$ & VI & VI & VIII & IX \\
\hline \multicolumn{10}{|l|}{ Northern Hemisphere } \\
\hline beringi Newell, 1951 & $?$ & $?$ & $?$ & $?$ & $?$ & $\begin{array}{l}71 \mathrm{~N}, 160 \mathrm{~W} \\
52-57 \mathrm{~N}, 173 \mathrm{E}-170 \mathrm{~W} \\
52-55 \mathrm{~N}, 158-166 \mathrm{E} \\
47-50 \mathrm{~N}, 152-56 \mathrm{E}\end{array}$ & $\begin{array}{l}\text { Arctic } \\
\text { Alaska } \\
\text { Kamchatka } \\
\text { Kuril Is }\end{array}$ & $0-39$ & algae, sand \\
\hline falcata (Hodge, 1863) & a & 0 & 4 & 6 & 2 & $\begin{array}{l}45-65 N, 21 W-21 E \\
41-45 N, 67-71 W \\
42-44 N, 3-16 \mathrm{E} \\
42-46 N, 28-38 \mathrm{E}\end{array}$ & $\begin{array}{l}\text { N Europe } \\
\text { NE America } \\
\text { Mediterranean } \\
\text { Black Sea }\end{array}$ & $0-300$ & $\begin{array}{l}\text { colonial organims, } \\
\text { algae, sediment, }\end{array}$ \\
\hline kervillei (Trouessart, 1894) & $\mathrm{a}$ & 0 & 2 & 6 & 1 & $38-53 \mathrm{~N}, 28 \mathrm{~W}-1 \mathrm{E}$ & N Europe & tidal & corallines, sand \\
\hline multisetosa Bartsch, 1986 & $\mathrm{a}$ & 0 & 2 & 6 & 1 & $\begin{array}{l}43 \mathrm{~N}, 5 \mathrm{E} \\
49-58 \mathrm{~N}, 4 \mathrm{~W}-11 \mathrm{E},\end{array}$ & $\begin{array}{l}\text { Mediterranean } \\
\text { N Europe }\end{array}$ & $10-45$ & sediment \\
\hline norvegica Viets, 1927 & $\mathrm{a}$ & 0 & 1 & 6 & 1 & $50-60 \mathrm{~N}, 5 \mathrm{~W}-4 \mathrm{E}$ & N Europe & 0 -sublittoral & \\
\hline nudipes Bartsch, 1977 & $\mathrm{a}$ & 0 & 1 & 5 & 0 & $49 \mathrm{~N}, 4 \mathrm{~W}$ & N Europe & tidal & sediment \\
\hline rustica Bartsch, 1977 & a & 0 & 2 & 5 & 1 & $49 \mathrm{~N}, 4 \mathrm{~W}$ & N Europe & tidal & crustose corallines \\
\hline steueri steueri Viets, 1940 & $\mathrm{a}$ & 0 & 3 & 5 & $1-2$ & $45 \mathrm{~N}, 14 \mathrm{E}$ & Mediterranean & $25-28$ & shell rubble, algae \\
\hline steueri reducta Bartsch, 1986 & $\mathrm{a}$ & 0 & 3 & 4 & $0-2$ & $43 \mathrm{~N}, 6 \mathrm{E}$ & Mediterranean & $20-40$ & sediment \\
\hline subfalcata Bartsch, 2003 & a & 0 & 3 & 6 & 2 & $30 \mathrm{~N}, 28 \mathrm{~W}$ & NE Atlantic & $318-321$ & \\
\hline \multicolumn{10}{|l|}{ Southern Hemisphere } \\
\hline africana Bartsch, 1992 & + & 1 & 4 & 6 & 1 & $33 \mathrm{~S}, 28 \mathrm{E}$ & South Africa & 0 & shell rubble \\
\hline antarctica Newell, 1984 & + & 0 & 4 & 6 & 2 & $\begin{array}{l}64 \mathrm{~S}, 64 \mathrm{~W} \\
66 \mathrm{~S}, 136 \mathrm{E} \\
77 \mathrm{~S}, 166 \mathrm{E}\end{array}$ & $\begin{array}{l}\text { Palmer Peninsula } \\
\text { Terre Adélie } \\
\text { Ross Island }\end{array}$ & $6-460$ & algae, bryozoans \\
\hline arenaria Bartsch, 1993 & + & 2 & 4 & 6 & 2 & $32 \mathrm{~S}, 115 \mathrm{E}$ & SW Australia & tidal & coarse sand \\
\hline bihamata Viets, 1950 & + & 0 & 1 & 6 & 2 & $52-54 \mathrm{~S}, 37-58 \mathrm{~W}$ & Falkland, S. Georgia & shallows & sand, rubble, algae \\
\hline bispina Newell, 1984 & + & 2 & 4 & 6 & 1 & $53 \mathrm{~S}, 72 \mathrm{~W}$ & Chile & tidal & coarse sand \\
\hline consimilis Bartsch, 1993 & + & 0 & 4 & 6 & 2 & $57 \mathrm{~S}, 27 \mathrm{~W}$ & S. Sandwich & $93-121$ & \\
\hline cygna Bartsch, 1988 & + & 0 & 5 & 8 & 2 & $9 \mathrm{~S}, 12 \mathrm{E}$ & Angola Basin & 1430 & \\
\hline dictyota Bartsch, 1992 & + & 1 & 2 & $7-8$ & 2 & $\begin{array}{l}16 \mathrm{~S}, 152 \mathrm{~W} \\
15-19 \mathrm{~S}, 145-151 \mathrm{E}\end{array}$ & $\begin{array}{l}\text { Society Islands } \\
\text { NE Australia }\end{array}$ & tidal-17 & coral rubble, coarse sand \\
\hline fukushimai Imamura, 1968 & $(+) \mathrm{s}$ & 0 & 4 & 7 & 2 & $\begin{array}{l}69 \mathrm{~S}, 31 \mathrm{E} \\
72 \mathrm{~S}, 172 \mathrm{E} \\
71-74 \mathrm{~S}, 12-29 \mathrm{~W}\end{array}$ & $\begin{array}{l}\text { Prince Harald Coast } \\
\text { Ross Sea } \\
\text { Weddell Sea }\end{array}$ & $190-820$ & \\
\hline gaussi Lohmann, 1907 & + & 0 & 4 & 7 & 2 & $\begin{array}{l}65 \mathrm{~S} 92 \mathrm{E} \\
56 \mathrm{~S}, 27 \mathrm{~W} \\
47 \mathrm{~S}, 38 \mathrm{E}\end{array}$ & $\begin{array}{l}\text { Wilhelm II Land } \\
\text { S. Sandwich } \\
\text { Marion Island }\end{array}$ & $95-385$ & \\
\hline
\end{tabular}


grandipora Newell, 1984

hureaui Newell, 1984

kerguelensis Lohmann, 1907

lamellipes Newell, 1984 masatierrae Newell, 1984 multispina Newell, 1984 pingsi Otto, 1994

rectangulops Newell, 1984 reticulata Viets, 1950

septemsetosa sp. nov.

setosa Newell, 1984

$\begin{array}{llllll}+ & 1-2 & 5 & 6 & 1 & 28-54 \mathrm{~S}, 71-72 \mathrm{~W} \\ + & 0 & 3 & 6 & ? & 54 \mathrm{~S}, 37 \mathrm{~W} \\ + & 0 & 4 & 7 & 2 & 50 \mathrm{~S}, 70 \mathrm{~W} \\ + & 0 & & & & 64 \mathrm{~S}, 61 \mathrm{~W} \\ + & 4-5 & ? & 6 & 2 & 53 \mathrm{~S}, 72 \mathrm{~W} \\ + & 0 & ? & 6 & ? & 34 \mathrm{~S}, 79 \mathrm{~W} \\ + & 3-4 & 3 & 5-6 & 1-2 & 18 \mathrm{~S}, 70 \mathrm{~W} \\ + & 0 & 4 & 7 & 2 & 35-38 \mathrm{~S}, 145-150 \mathrm{E} \\ + & 0 & 2 & 5 & 1 & 32 \mathrm{~S}, 115 \mathrm{E} \\ + & 0 & 3-4 & 6 & 1 & 53 \mathrm{~S}, 72 \mathrm{~W} \\ + & 0 & 4 & 7 & 2 & 34 \mathrm{~S}, 122 \mathrm{E} \\ + & 0 & 4 & & & \\ + & 0 & 3 & 6 & 2 & 26 \mathrm{~S}, 80 \mathrm{~W}\end{array}$

Chile
S. Georgia
Kerguelen
Kerguelen
Palmer Peninsula
Chile
Chile
Chile
S and SE Australia
SW Australia
Chile
Falklands
SW Australia
Chile

coarse shell, sand,

holdfasts

shallows

shallow-58

shallows

shallows

tidal

tidal

tidal

tidal

12-16

low water

tidal

holdfasts with sand

red algae

shell rubble

corallines

corallines, bivalves

sand, rubble, algae

sand with algae

corallines

I. Number of gland pores: a, one or more pairs of pores lacking; + , five pairs present; $(+)$ s, one or more of the five pairs replaced by setae

II. P-2, number of spiniform processes:

III. I-4, number of bipectinate setae:

IV. I-5, number of bipectinate setae:

V. I- 6 , number of bipectinate setae:

VI. Collecting area, coordinates:

VII. Collecting area, state/province/island or sea area:

VIII. Depth (in $\mathrm{m}$ ):

IX. Habitat:

Table 2 Freshwater Lohmannella species and collecting data.

\begin{tabular}{lll}
\hline species & country & salinity \\
\hline andrei (Angelier, 1951) & France & fresh \\
curvimandibulata (Petrova, 1966) & Bulgaria & fresh \\
cuetkovi (Petrova, 1965) & Bulgaria & fresh \\
heptapegoni Petrova, 1966 & Israel & fresh \\
stammeri Viets, 1939 & Italy, Monte Negro & fresh, slightly brackish \\
\hline
\end{tabular}


Table 3 The genus Simognathus. List of species, morphological characters and collecting data.

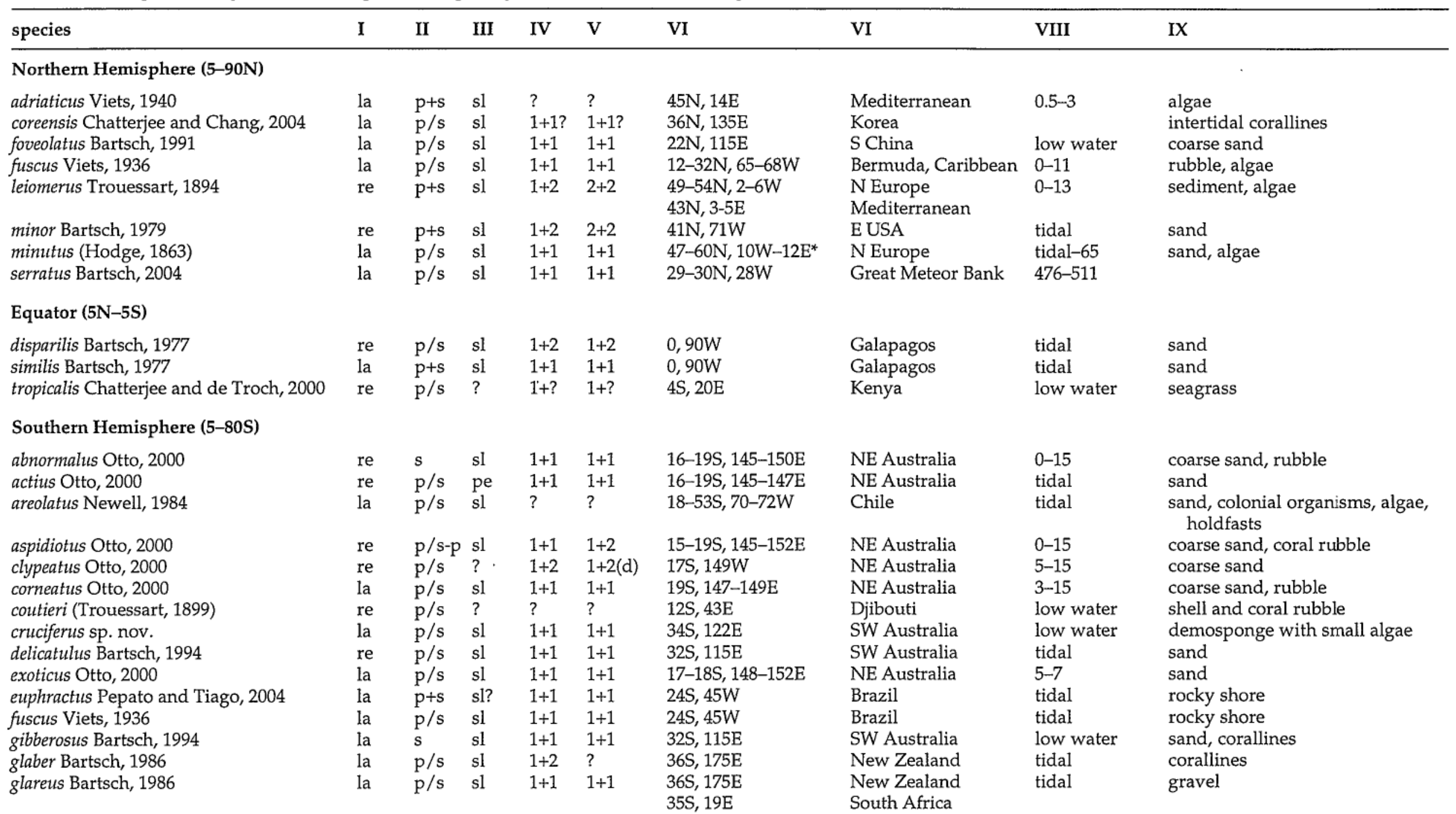




$\begin{array}{lllll}\text { re } & \mathrm{s} & \mathrm{sl} & 1+1 & 1+1 \\ \text { la } & \mathrm{p}+\mathrm{s} ? & \mathrm{sl} & ? & ? \\ \text { la } & \mathrm{p}+\mathrm{s} ? & \mathrm{w} & 1+2 & 1+2 ? \\ \mathrm{la} & \mathrm{p} / \mathrm{s} & \mathrm{sl} & 1+1 & 1+1 \\ \text { la } & \mathrm{p} / \mathrm{s} & \mathrm{sl} & ? & ?\end{array}$

$32 \mathrm{~S}, 115 \mathrm{E}$

18-53S, 70-72W

$30 \mathrm{~S}, 30 \mathrm{E}$

$32 \mathrm{~S}, 115 \mathrm{E}$

53-55S, $71 \mathrm{~W}$

$52 \mathrm{~S}, 58 \mathrm{~W}$

$54 \mathrm{~S}, 159 \mathrm{~W}$

$55 \mathrm{~S}, 159 \mathrm{E}$

obtusus Newell, 1971

pectinatus Newell, 1984

platyaspis Otto, 2000

pygmaeus Otto, 2000

salebrosus Bartsch, 2003

scutatus Bartsch, 1993

specialis Otto, 2000

subobtusus Newell, 1984

tener Bartsch, 2003

trachys Otto, 2000

uniscutatus Bartsch 1994

variolosus Bartsch, 1994

versicolor Otto, 2000

xandarus Otto, 2000

$\begin{array}{lllll}\text { la } & \mathrm{p} / \mathrm{s} & \mathrm{sl} & ? & ? \\ \text { re } & \mathrm{p}+\mathrm{s} ? & \text { sl } & ? & ? \\ \text { la } & \mathrm{p} / \mathrm{s} & \mathrm{sl} & 1+1 & 1+1\end{array}$

26-33S, 72-80W

$17-27 \mathrm{~S}, 70-71 \mathrm{~W}$

15-28S, 145-147E

21S, 117E

10S, 124E

$\begin{array}{lllll}\text { re } & s & \text { sl } & 1+2 & 1+2 \\ \text { re } & s & \text { sl } & 1+1 & 1+1\end{array}$

$16 \mathrm{~S}, 145 \mathrm{E}$

21S, 117E

$32 \mathrm{~S}, 115 \mathrm{E}$

15-18S, 147-150E

$\mathrm{p} / \mathrm{s}$ sl $1+1 \quad 1+1$

$\mathrm{p} / \mathrm{s}$ sl $1+1 \quad 1+1$

$\begin{array}{llll}\mathrm{p} / \mathrm{s} & \mathrm{sl} & ? & ? \\ \mathrm{p} / \mathrm{s} & \mathrm{sl} & 1+2 & 1+2\end{array}$

$\begin{array}{llll}\mathrm{s} & \mathrm{sp} & 1+1 & 1+1\end{array}$

34S, $79 \mathrm{~W}$

21S, 117E

$19 \mathrm{~S}, 149 \mathrm{E}$

$32 \mathrm{~S}, 115 \mathrm{E}$

21S, 116E

21S, 116E

s sl $\quad 1+2 \quad 1+2 \quad 32 S, 115 \mathrm{E}$

$\mathrm{p} / \mathrm{s} \quad \mathrm{sl} \quad 1+1 \quad 1+1 \quad 19 \mathrm{~S}, 149 \mathrm{E}$

$\mathrm{p} / \mathrm{s}$ sl $\quad 1+1 \quad 1+1 \quad 19-22 \mathrm{~S}, 147-153 \mathrm{E}$

SW Australia

Chile

South Africa

SW Australia

Chile

Falklands

Macquarie Ridge

Chile

Chile

NE Australia

NW Australia

Philippines

NE Australia

NW Australia

SW Australia

NE Australia

Chile

NW Australia

NE Australia

SW Australia

NW Australia

SW Australia

NE Australia

NE Australia
30

tidal-shallows worm tubes, holdfasts

tidal algae

0.5

seagrasses

tidal-278 algae, corallines, holdfasts,

barnacles

\section{$88-278$}

92-113

tidal-190 corallines, mussels, coarse sand

tidal

$0-6$

low water

10-15

tidal

tidal

tidal

$0.5-15$

tidal

tidal

10

$2-13$

tidal

10

3-15

shell fragments, worm tubes

sand, rubble, coral fragments

coral block

sand and algae

sand

sand

coarse sand

algae, coarse sand, coral rubble

algae

coarse sand

coarse sand, coral rubble

sand

sand

coral rubble

medium to coarse sand

Shape of OC: re, reduced; la, large, triangular or rounded.

II. P-2: $\mathrm{p} / \mathrm{s}$, with protuberance and distal seta; $\mathrm{p} / \mathrm{s}-\mathrm{p}$, with protuberance and distal seta and a small distal protuberance; $\mathrm{p}+\mathrm{s}$, protuberance and seta at same level; $\mathrm{s}$, seta only, protuberance lacking.

III. I-5, shape of ventromedial seta: pe, bipectinate; sl, slender; sp, spiniform; w, wide though setiform.

IV. III- 6 , number of ventral and parambulacral setae: $1+1$, either one ventral and one parambulacral seta or two ventral setae and parambulacral setae lacking; $1+2$, one ventral seta and pair of parambulacral setae; $1+2(d)$, one ventral seta and pair of parambulacral setae, one of pas doubled; $2+2$, two ventral and pair of parambulacral setae.

V. IV-6, number of ventral and parambulacral setae: character states as above.

VI. Collecting area, coordinates:

VII. Collecting area, state/province/island or sea area:

VIII. Depth (in m)

IX. Habitat:

* doubtful records excluded; ?, information lacking or in need of confirmation. 
bathyal $(0-500 \mathrm{~m})$. Representatives of the genus inhabit coarse sand, rubble, crustose and other algae, seagrasses, colonies of polychaetes and barnacles. There is a strikingly high diversity in the Australian fauna (Figure 6), 12 species being recorded from Queensland and 10 species from Western Australia. Though knowledge of the halacarid fauna of New Zealand is meagre, two of the 23 marine species recorded are representatives of Simognathus. From the southern South American continent six Simognathus species are recorded (Newell, 1984). Almost 70 marine halacarid species are known in total (Newell 1984; Bartsch 1988b, 1989). In contrast, only two out of 90 species in the Mediterranean, and two out of the known 120 shallow water halacarid species in the northeastern Atlantic, belong to the genus Simognathus. From eastern North America there is just a single record (Bartsch 1979b).

Table 3 presents a list of Simognathus species, their geographical areas and habitats, and some of their morphological characters. Simognathus species can roughly be divided into those with large $O C$, round or triangular in shape, and those with the $O C$ reduced to narrow sclerites which often are obscured by the striated integument. Other characters are the shape of P2 , with or without any protuberance, and the number and arrangement of tarsal setae. Both in the north and south there are species with reduced $O C$, and the reduction seems to be correlated with a mesopsammal life style. Palps with the seta of $\mathrm{P}-2$ and the protuberance situated at the same level are present in northern as well as in southern species. According to the setation of tarsi III and IV, S. leiomerus and $S$. minor are closely related. Other siblings are $S$. abnormalus and S. salebrosus; they share the characters: tibia I widest near its base, tarsus I very short and rotated versus the leg's axis, and presence of epimeral fossae. These characters are absent in other species.

Looking at the present day distributional records, one may expect Simognathus to be a Gondwanan genus with several founder species dispersing to the European, North American and Asian coastlines. More detailed analysis is necessary to eluciate these patterns.

\section{ACKNOWLEDGEMENTS}

The three species described were collected during two Marine Biological Workshops in Western Australia, on Rottnest Island and in Esperance. The workshops were organized by Dr F. Wells and colleagues. The travel expenses were covered by the Deutsche Forschungsgemeinschaft. To all my sincerest thanks.

\section{REFERENCES}

Bartsch, I. (1978). Halacaridae (Acari) aus der Tiefsee des atlantischen Ozenas. Cahiers de Biologie marine 19: 4762.

Bartsch, I. (1979a). Halacaridae (Acari) aus der Subantarktis. Cahiers de Biologie marine 20: 325-339.

Bartsch, I. (1979b). Halacaridae (Acari) von der Atlantikküste Nordamerikas. Beschreibung der Arten. Mikrofauna Meeresboden 79: 1-62.

Bartsch, I. (1982). Weitere Halacaridae (Acari) aus dem Kanal von Moçambique. Cahiers de Biologie marine 23: 435-457.

Bartsch, I. (1988a). Deep-sea halacarids (Acari) and description of a new species. Journal of Natural History 22: 811-821.

Bartsch, I. (1988b). Thalassophthirius auster gen. et spec. nov., a halacarid mite (Acari) suspected of being a parasite. Polar Research 6: 181-184.

Bartsch, I. (1989). Rhombognathus auster, a new rhombognathine mite (Acari, Halacaridae) from southern South America. Zoologica Scripta 18: 423-425.

Bartsch, I. (1992). Lohmannella dictyota n. sp. und $L$. africana n. sp. von der Südhalbkugel (Arachnida: Acari: Halacaridae). Senckenbergiana biologia 72: 457464.

Bartsch, I. (1993a). Synopsis of the Antarctic Halacaroidea (Acari), In J.W. Wägele and J. Sieg (eds) Synopses of the Antarctic Benthos 4: 1-176. Koeltz Scientific Books, Koenigstein.

Bartsch, I. (1993b). Arenicolous Halacaridae (Acari) from south-western Australia, In F.E. Wells, D.I. Walker, H. Kirkman \& R. Lethbridge (eds), The Marine Flora and Fauna of Rottnest Island, Western Australia: 45-71. Western Australian Museum, Perth.

Bartsch, I. (1994). The genus Simognathus (Acari : Halacaridae), description of six new species from southern Australia and a tabular key to all species. Acarologia 35: 135-152

Bartsch, I. (1996). Halacarids (Halacaroidea, Acari) in freshwater. Multiple invasions from the Paleozoic onwards. Journal of Natural History 30: 67-99.

Bartsch, I. (2003a). Halacarids (Acari) from coral reefs off Norway, Northern Atlantic: Description of a new Agauopsis species. Entomologische Mitteilungen aus dem Zoologischen Museum Hamburg 14: 117-123.

Bartsch, I. (2003b). Psammophilous halacarids (Halacaridae, Acari) from Dampier, Western Australia. Description of species and faunal comparison of the mesopsammal halacarid fauna of western and eastern Australia. Records of the Western Australian Museum 22: 23-45.

Bartsch, I. (2004). Halacaridae (Acari) from the Great Meteor Seamount (Northeastern Atlantic). Description of Simognathus species. Mitteilungen aus dem hamburgischen zoologischen Museum und Institut 101: 185-196.

Chatterjee, T. and Chang, C.Y. (2004). Simognathus coreensis, a new halacarid mite (Halacaridae: Acari) from Korea. Hydrobiologia 529: 271-274.

Knox, G.A. (1963). The biogeography and intertidal ecology of the Australasian coast. Oceanography and marine Biology. Annual Review 1: 341-404. 
Lohmann H. (1907). Die Meeresmilben der Deutschen Südpolar-Expedition 1901-1903. Deutsche Siidpolar Expedition 1901-1903, 9: 361-413.

Makarova, N.G. (1977). Marine mites (Acarina, Halacaridae) of the intertidal zone of the Kurile Islands. Fauna pribreznih zon kurilskih ostrovov 125-143. (In Russian)

Makarova, N.G. (1978). Marine mites (Acarina, Halacaridae) of the intertidal zone of the Gulf of Anadyr (Bering Sea). In O.G. Kussakin (ed.) The intertidal zone of the Bering Sea and southeastern Kamchatka 131-149. Publishing House Nauka, Moskau (In Russian, with English summary).

Murray, A. (1877). Economic Entomology. Aptera. South Kensington Museum Handbooks, London, 433 pp.

Newell, I.M. (1947). A systematic and ecological study of Halacaridae of eastern North America. Bulletin of the Bingham oceanographic Collection 10: 1-232.

Newell, I.M. (1951). Further studies on Alaskan Halacaridae (Acari). American Museum Novitates 1536: 1-56.

Newell I.M. (1984). Antarctic Halacaroidea. Antarctic Research Series 40: 1-284.

O'Hara, T.D. and Poore, G.C.B. (2000). Patterns of distribution for southern Australian marine echinoderms and decapods. Journal of Biogeography 27: 1321-1335.

Otto, J.C. (1994). New species of Halacaridae from Australia (Acarina : Prostigmata). Acarologia 35: 3148.

Otto, J.C. (2000). Halacaridae from the Great Barrier Reef and Coral Sea: the genera Lohmannella, Scaptognathides and Scaptognathus (Acarina: Halacaridae: Lohmannellinae). Memoirs of the Queensland Museum 45: 535-555
Pepato, A.R. and Tiago, C.G. (2004). The genera Acaromantis and Simognathus (Simognathinae, Halacaridae) on the north coast of São Paulo State, Brazil. Zootaxa 615: 1-16.

Pesic, V. (2004). Three interesting halacarid mite species (Acari: Halacaroidea) from Montenegro and Italy. Lauterbornia 49: 37-42.

Ponder, W.F. and Wells, F.E. (1998). Distribution and relationships of marine and estuarine fauna. In P.L. Beesley, G.J.B. Ross and A. Wells (eds), Mollusca: The Southern Synthesis. Fauna of Australia 5A, 77-80. CSIR Publishing, Melbourne.

Trouessart, E. (1889). Sur les acariens marins des côtes de France. Compte rendu de l'Académie des Sciences, Paris 108: 1178-1181.

Trouessart, E. (1901). Note sur les acariens marins (Halacaridae) récoltés par M. Henri Gadeau de Kerville dans la région d'Omonville-la-Rouge (Manche) et dans la fosse de la Hague (Juin-Juillet 1899). Bulletin de la Société des amis des sciences naturelles de Rouen (Série 4) 14: 247-266.

Viets, K. (1927): Die Halacaridae der Nordsee. Zeitschrift für wissenschaftliche Zoologie 130: 83-173.

Wells, F.E. and Walker, D.I. (1993). Introduction. In F.E. Wells, D.I. Walker, H. Kirkman and R. Lethbridge (eds), The Marine Flora and Fauna of Rottnest Island, Western Australia: 1-10. Western Australian Museum, Perth.

Wilson, B.R. and Allen, G.R. (1987). Major components and distribution of marine fauna. In G.R. Dyne, and D.W. Walton (eds), Fauna of Australia 1A, 43-68. Australian Goverment Publishing Service, Canberra.

Manuscript received 4 August 2004; accepted 21 January 2005 